\title{
First Record of the Critically Endangered Three-striped Roofed Turtle, Batagur dhongoka (Gray 1834), from the Yamuna River, Delhi, India
}

\author{
Gaurav Barhadiya ${ }^{1}$, Aisha Sultana ${ }^{2}$, and Mohammad Shah Hussain ${ }^{2}$
}

${ }_{1}^{1}$ Department of Environmental Studies, University of Delhi, New Delhi, Delhi-110007, India (Gaurav7wild7@gmail.com) ${ }^{2}$ Biodiversity Parks Programme, Centre for Environmental Management of Degraded Ecosystems (CEMDE), University of Delhi, New Delhi, Delhi-110007, India

Tndia is home to 29 species of freshwater turtles and tortoises belonging to four different families (Ahmed et al. 2009). Of the three species in the genus Batagur (Bataguridae), Batagur dhongoka (formerly Kachuga dhongoka) is endemic to India, Nepal, and Bangladesh (Iverson 1992). In India, the species is restricted to the north (Smith 1931), where it occurs in the Ganga and Chambal Rivers and their floodplains (Moll and Moll 2004; Sirsi et al. 2017). These turtles have been recorded from the states of Uttar Pradesh, Rajasthan, Madhya Pradesh, Bihar, West Bengal, and Assam (Das et al. 2019; Bhupathy and Mathur 2013) but not from Delhi (Husain 1997).

Delhi once supported robust populations of several aquatic reptiles, including the Mugger Crocodile (Crocodylus palustris), the Gharial (Gavialis gangeticus), and two species of soft-shelled turtles (Husain 1997). However, due to rapid urbanization and habitat fragmentation, riverine biodiversity has declined considerably.

At 1737 h on 1 February 2019, in the course of a biodiversity assessment in Delhi, we encountered a live Three- striped Roofed Turtle (Batagur dhongoka) (carapace length of $38 \mathrm{~cm}$; Fig. 1) on the bank of the Yamuna River in the Alipur Region of northwestern Delhi ( $\left.28^{\circ} 47^{\prime} 58.1^{\prime \prime N}, 77^{\circ} 12^{\prime} 10.2^{\prime \prime E}\right)$ (Fig. 2). The area was sandy with scattered grasses and shrubs. We identified the turtle based on a description in Smith (1931), which was later confirmed by Dr. Shailendra Singh.

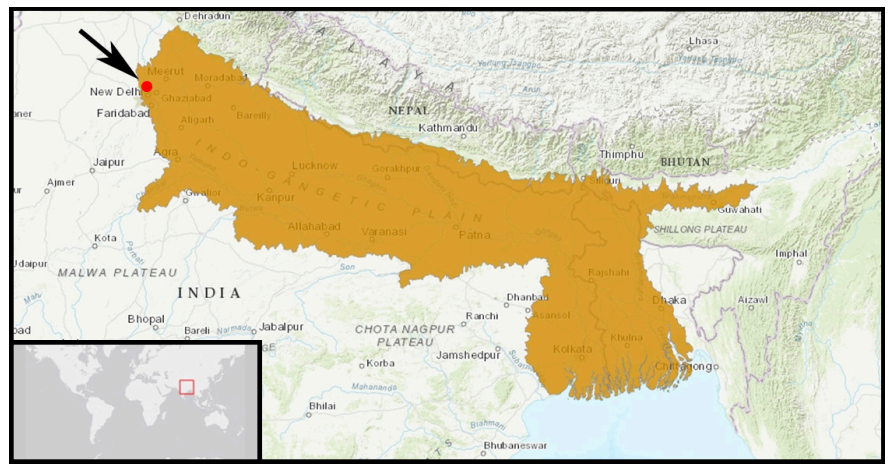

Fig. 2. Distribution of the Three-striped Roofed Turtle (Batagur dhongoka). The red dot indicated by an arrow marks the locality in the Yamuna River, Dehli, India. Modified from Das et al. (2019).
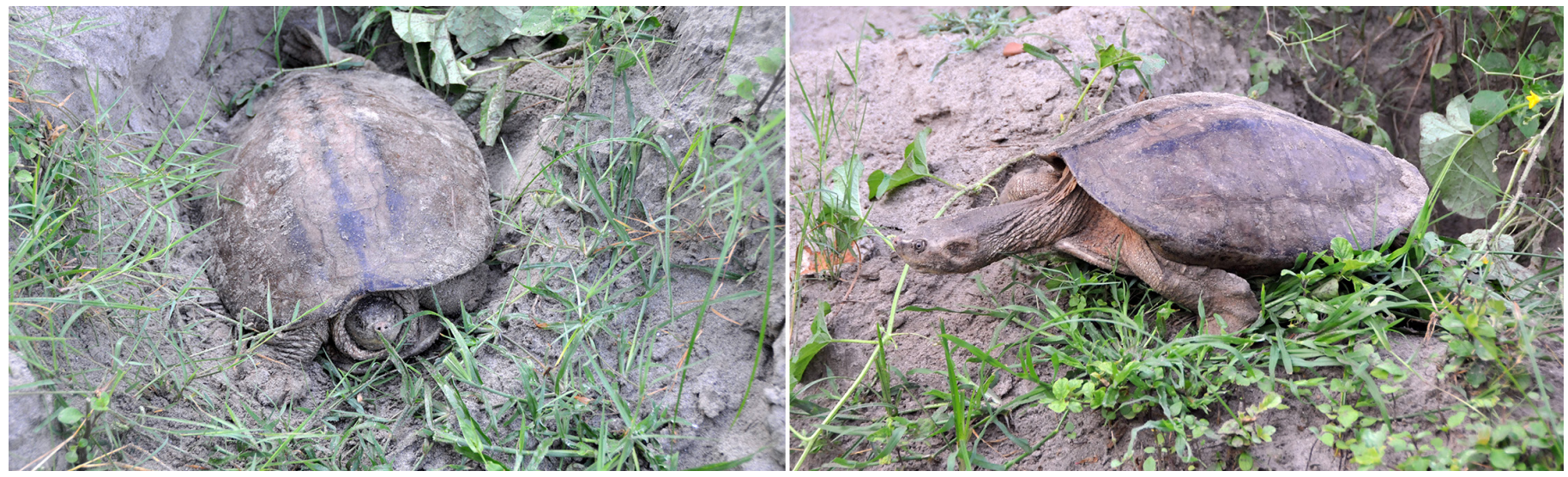

Fig. 1. A Three-striped Roofed Turtle (Batagur dhongoka) on the bank of the Yamuna River, Delhi, India. Photographs by Gaurav Barhadiya. 
To the best of our knowledge, this is the first record of a Three-striped Roofed Turtle from the Yamuna River and the state of Delhi.

The closest historical record of Batagur dhongoka is in the Hindon River at Ghaziabad, Uttar Pradesh (Moll 1986, 1987). Subsequently, few turtle surveys have been conducted in the Delhi National Capital Region (Husain 1997). Das (1991) stated that Batagur dhongoka was once fairly common in the Ganga River and its floodplain. However, the population declined rapidly due to various threats that include overharvesting, sand mining, and pollution from urban, industrial, and agricultural sources (Chaudhury et al. 2000; Sirsi et al. 2017; Das et al. 2019). Although this species is listed as Critically Endangered on the IUCN Red List (Das et al. 2019), it lacks any legal protection in India, where it is still not listed under the Indian Wildlife Protection Act, 1972.

\section{Acknowledgements}

We are extremely thankful to Dr. Shailendra Singh, Director, Turtle Survival Alliance (TSA) India, for confirming the identity of the turtle.

\section{Literature Cited}

Ahmed, M.F., A. Das, and S.K. Dutta. 2009. Amphibians and Reptiles of Northeast India: A Photographic Guide. Aaranyak, Guwahati, India.
Bhupathy, S. and R. Mathur. 2013. Chelonian status and conservation in Rajasthan, pp. 277-286. In: B. Sharma, S. Kulshreshtha, and A. Rahmani (eds.), Faunal Heritage of Rajasthan, India. Springer, New York, New York.

Choudhury, B.C., S. Bhupathy, and F. Hanfee. 2000. Status information on the tortoises and freshwater turtles of India, pp. 86-94. In: P.P. van Dijk, B.L. Stuart, and A.G.J. Rhodin (eds.), Asian Turtle Trade: Proceedings of a Workshop on Conservation and Trade of Freshwater Turtles and Tortoises in Asia. Chelonian Research Monographs No. 2. Chelonian Research Foundation, Lunenburg, Massachusetts.

Das, I. 1991. Colour Guide to the Turtles and Tortoises of the Indian Subcontinent. R\&A Publishing Ltd., Portishead, Avon, England.

Das, I., B.C. Choudhury, P. Praschag, M.F. Ahmed, and S. Singh. 2019. Threestriped Roofed Turtle. Batagur dhongoka (errata version published in 2019). The IUCN Red List of Threatened Species 2019: e.T10953A499894.

Husain, A. 1997. Reptilia, pp. 665-698. In: J.R.B. Alfred (ed.), Fauna of Delhi. Zoological Survey of India, Dehradun, India.

Iverson, J.B. 1992. A Revised Checklist with Distribution Maps of the Turtles of the World. Privately published, Richmond, Indiana.

Moll, D. and E.O. Moll. 2004. The Ecology, Exploitation and Conservation of River Turtles. Oxford University Press, New York, New York.

Moll, E.O. 1986. Survey of the freshwater turtles of India. Part I: The genus Kachuga. Journal of the Bombay Natural History Society 83: 538-552 + plate I.

Moll, E.O. 1987. Survey of the freshwater turtles of India. Part II: the genus Kachuga. Journal of the Bombay Natural History Society 84: 7-25 + plates IIIII.

Sirsi, S., S. Singh, A. Tripathi, S.F. McCracken, M.R. Forstner, and B.D. Horne. 2017. Variation in reproductive output of the Red-crowned Roofed Turtle (Batagur kachuga) and the Three-striped Roofed Turtle (Batagur dhongoka) in the Chambal River of north India. Chelonian Conservation and Biology 16: 203-214.

Smith, M.A. 1931. The Fauna of British India, Ceylon and Burma, Including the Whole of the Indo-Chinese Sub-region. Reptilia and Amphibia. Vol. I.Testudines. Taylor \& Francis, London, England. 